\title{
Pengaruh Gaya Kepemimpinan, Motivasi Kerja Dan Disiplin Kerja Terhadap Kinerja Guru Smpn 3 Salimpaung Kabupaten Tanah Datar
}

\author{
Yosi Puspita Sari \\ Universitas Putra Indonesia YPTK Padang \\ Email : yosipuspita18@gmail.com
}

\begin{abstract}
Abstrak
Penelitian ini bertujuan untuk mengungkapkan Pengaruh gaya kepemimpinan, motivasi kerja,disiplin kerja terhadap kinerja guru SMPN 3 Salimpaung Kabupaten Tanah Datar. Populasi penelitian ini adalah semua guru SMPN 3 Salimpaung yang berjumlah 43 orang . sampel di ambil dari semua populasi 43 orang.

Hasil penelitian di dapatkan (1)Secara parsial Gaya Kepemimpinan, Motivasi Kerja dan Disiplin kerja berpengaruh positif dan signifikan terhadap Kinerja Guru SMPN 3 Salimpaung Kabupaten Tanah Datar. (2) Secara simultan Pengaruh Gaya Kepemimpinan (X1), Motivasi Kerja (X2), Disiplin Kerja (X3) terhadap Kinerja Guru (Y) adalah sig. sebesar 0,04, nilai sig lebih kecil dari alpha 0.05 dan nilai $\mathrm{F}_{\text {hitung }}$ sebesar 11,141 , sedangkan nilai $\mathrm{F}_{\text {tabel }}$ adalah 2,845, sehingga nilai $\mathrm{F}_{\text {hitung }}$ lebih besar dari nilai $\mathrm{F}_{\text {tabel, }}$ dan persamaan regresi untuk variabel Gaya Kepemimpinan, Motivasi kerja dan Disiplin kerja adalah $\mathrm{Y}=-10.217+0.254 \mathrm{X}_{1}+0.481 \mathrm{X}_{2}+$ $0.702 \mathrm{X}_{3}+\mathrm{e}$, maka dapat disimpulkan bahwa Gaya Kepemimpinan (X1), Motivasi Kerja (X2) dan Disiplin Kerja (X3) terbukti berpengaruh secara positif dan signifikan terhadap Kinerja Guru SMPN 3 Salimpaung Kabupaten Tanah Datar.
\end{abstract}

Kata Kunci : Gaya Kepemimpinan, Motivasi Kerja ,Disiplin Kerja dan Kinerja Guru.

\section{Pendahuluan}

Sektor pendidikan senantiasa merupakan ujung tombak bagi maju atau mundurnya suatu negara termasuk Indonesia. Dengan kata lain, tidak ada suatu Negara di dunia ini yang dapat dikatakan maju tanpa diiringi oleh kemajuan pendidikan dinegara tersebut. Untuk mendapatkan sumber daya manusia yang berkualitas adalah melalui pendidikan. Pendidikan adalah modal dasar untuk menciptakan SDM yang unggul. Dunia pendidikan yang utama adalah sekolah. Sekolah merupakan salah satu lembaga alternatif pelayanan pendidikan.

Berdasarkan Standar Kualitas Rencana Pelaksanaan Pembelajaran (RPP) yang diatur oleh Peraturan Pemerintah No 19 Tahun 2005 Pasal 20 bahwa perencanaan proses pembelajaran meliputi silabus dan rencana pelaksanaan pembelajaran yang wajib diserahkan sebagai bukti proses pembelajaran dan kelengkapan administrasi sekolah dan sebagai bukti gambaran kinerja guru, berikut gambaran kinerja guru dapat dilihat dari data penyerahan RPP guru pada empat tahun ajaran terakhir :

Tabel . Penyerahan Rencana pelaksanaan Pembelajaran (RPP)

\begin{tabular}{cccccc}
\hline NO & $\begin{array}{c}\text { TAHUN } \\
\text { AJARAN }\end{array}$ & MENYERAHKAN & $\%$ & $\begin{array}{c}\text { TIDAK } \\
\text { MENYERAHKAN }\end{array}$ & $\%$ \\
\hline 1 & $2012 / 2013$ & 15 & $45 \%$ & 18 & $55 \%$ \\
2 & $2013 / 2014$ & 18 & $55 \%$ & 15 & $45 \%$ \\
3 & $2014 / 2015$ & 19 & $58 \%$ & 14 & $42 \%$ \\
4 & $2015 / 2016$ & 22 & $66 \%$ & 11 & $34 \%$ \\
\hline
\end{tabular}


Tabel 1 telah memberikan penjelasan bahwa masih ada 34\% guru SMPN 3 Salimpaung yang tidak menyerahan RPP pada satu tahun terakhir sesuai dengan aturan yang telah ditetapkan, artinya masih ada guru yang melanggar aturan, maka administrasi dan aplikasi kinerja guru di sekolah tidak dapat dijalankan sesuai dengan prosedur.

Salah satu indikator dalam komponen suatu sekolah dianggap sudah berhasil adalah hasil belajar atau output, jika pada SMPN 3 Salimpaung dapat dilihat dari perolehan nilai Ujian Nasional dan tingkat kelulusan yang maksimal. Sekolah yang perolehan nilai ujian nasionalnya paling tinggi dan tingkat kelulusannya setiap tahun selalu $100 \%$ dianggap telah berhasil dan akan mendapat kepercayaan masyarakat. Karena masyarakat bisa melihat salah satu kinerja guru dari hasil ujian tersebut. Pada SMPN 3 Salimpaung yang terletak di Jalan Tabing Luak Sumanik Kabupaten Tanah Datar, berikut dapat dilihat hasil rata-rata nilai Ujian Nasional (UN) dan prosentasi kelulusan dalam empat tahun terakhir.

Tabel 2. Rata-Rata Nilai Ujian Nasional dan Kelulusan

\begin{tabular}{llllll}
\hline No & Mata Pelajaran & $2012 / 2013$ & $2013 / 2014$ & $2014 / 2015$ & $2015 / 2016$ \\
\hline 1 & B. Indonesia & 7,46 & 6,90 & 6,25 & 7,43 \\
2 & B Inggris & 6,46 & 6,41 & 6,39 & 7,27 \\
3 & Matematika & 6,07 & 6,31 & 6,20 & 7,46 \\
4 & IPA & 6,07 & 7,07 & 6,13 & 6,95 \\
& Rata-rata & 6,52 & 6,67 & 6,24 & 7,28 \\
& \% Lulusan & $100 \%$ & $100 \%$ & $100 \%$ & $100 \%$ \\
\hline
\end{tabular}

Kinerja guru di sekolah mempunyai peran penting dalam pencapaian tujuan sekolah. Masalah kinerja menjadi sorotan berbagai pihak, kinerja pemerintah akan dirasakan oleh masyarakat dan kinerja guru akan dirasakan oleh siswa atau orang tua siswa. Berbagai usaha dilakukan untuk mencapai kinerja yang baik. Perhatian pemerintah terhadap pendidikan sudah disosialisasikan, anggaran pendidikan yang diamanatkan Undang-Undang $20 \%$ sudah mulai dilaksanakan. Maka kinerja guru tentunya akan menjadi perhatian semua pihak. Guru harus benar-benar kompeten dibidangnya dan guru juga harus mampu mengabdi secara optimal. Kinerja guru yang optimal dipengaruhi oleh berbagai faktor, baik internal maupun eksternal.

Adapun tujuan penelitian ini untuk mengetahui dan menguji secara empirik : (1)Pengaruh gaya kepemimpinan secara parsial terhadap kinerja guru pada SMPN 3 Salimpaung Kabupaten Tanah Datar, (2.)Pengaruh motivasi kerja secara parsial terhadap kinerja guru pada SMPN 3 Salimpaung Kabupaten Tanah Datar. (3)Pengaruh disiplin kerja secara parsial terhadap kinerja guru pada SMPN 3 Salimpaung Kabupaten Tanah Datar. (4)Pengaruh gaya kepemimpinan ,motivasi dan disiplin kerja secara simultan terhadap kinerja guru pada SMPN 3 Salimpaung Kabupaten Tanah Datar.

\section{Metodologi Penelitian}

Penelitian ini menggunakan Metode Survey. Metode Survey adalah penelitian yang dilakukan pada populasi besar maupun kecil, tetapi data yang dipelajari adalah data dari sampel yang diambil dari populasi tersebut, sehingga dapat ditemukan kejadian-kejadian relatif, distributif dan hubungan antar variabel, sosiologis maupun psikologis. Sedangkan bentuk penelitiannya adalah penelitian deskriptif. Penelitian deskriptif adalah mempelajari masalah-masalah deskriptif dalam masyarakat, serta tata cara yang berlaku dalam mastar akat serta situasi-situasi tertentu, termasuk tentang hubungan kegiatankegiatan , sikap-sikap ,pandangan, serta proses-proses yang sedang berlangsung dan pengaruhpengaruh dari fenomena. Penelitian ini dilakukan pada SMP Negeri 3 Salimpaung Kabupaten Tanah Datar. 
Populasi penelitian ini adalah semua guru SMP Negeri Salimpaung Kabupaten Tanah Datar yang berjumlah 43 Orang. karena populasi kurang dari 100 orang ,maka sampel penelitian ini adalah seluruhnya dari jumlah populasi yang ada yakni sebanyak 43 orang. Sehingga teknik pengambilan sampel adalah secara total population.

\section{Hasil Dan Pembahasan}

Tabel 3 Regresi Gaya Kepemimpinan, Motivasi Kerja, DisiplinKerja Serta Pengaruhnya terhadap Kinerja Guru

\begin{tabular}{|c|c|c|c|c|c|c|}
\hline \multirow{3}{*}{ Model } & & \multicolumn{4}{|c|}{ Coefficients $^{\mathrm{a}}$} & \multirow[b]{2}{*}{ Sig. } \\
\hline & & \multicolumn{2}{|c|}{$\begin{array}{l}\text { Unstandardized } \\
\text { Coefficients }\end{array}$} & $\begin{array}{c}\text { Standardized } \\
\text { Coefficients }\end{array}$ & & \\
\hline & & $\mathrm{B}$ & Std. Error & Beta & & \\
\hline \multirow{4}{*}{1} & (Constant) & -10.217 & 6.400 & $\mathrm{t}$ & -1.596 & .113 \\
\hline & GAYA KEPEMIMPINAN & .254 & .122 & .239 & 2.089 & .043 \\
\hline & MOTIVASI KERJA & .481 & .189 & .356 & 2.546 & .015 \\
\hline & DISIPLIN KERJA & .702 & .294 & .332 & 2.388 & .022 \\
\hline
\end{tabular}

Berdasarkan pengolahan data nilai penduga koefisien regresi berganda untuk melihat pengaruh dari masing-masing variabel bebas yaitu Gaya Kepemimpinan, Motivasi Kerja dan Disiplin Kerja dalam suatu persamaan regresi yang disajikan pada tabel 3 tersebut di atas memperlihatkan hasil regresi berganda dengan nilai konstanta -10.217 dan variable kepemimpinan 0.254, variable motivasi 0.481, variable Motivasi 0.702 maka diperoleh persamaan :

$$
\begin{aligned}
& Y=\alpha+b_{1} X_{1}+b_{2} X_{2}+b_{3} X_{3}+e \\
& Y=-\mathbf{1 0 . 2 1 7 + 0 . 2 5 4} X_{1}+\mathbf{0 . 4 8 1}_{\mathbf{2}}+\mathbf{0 . 7 0 2}_{\mathbf{3}}+\mathbf{e}
\end{aligned}
$$

Dari persamaan di atas diketahui bahwa nilai konstanta untuk ketiga variabel sebesar 10.217dan variabel independen yang pertama yaitu gaya kepemimpinan memiliki nilai koefisien regresi sebesar 0.254 artinya bila kepemimpinan meningkat satu unit maka akan meningkatkan Kinerja Guru sebesar 0.254 satuan, demikan sebaliknya. bila gaya kepemimpina menurun satu unit maka akan menurunkan Kinerja Guru sebesar 0.254 satuan.

Untuk variabel independen yang kedua yaitu motivasi memiliki nilai koefisien regresi sebesar 0.481 artinya bila motivasi kerja meningkat satu unit maka akan meningkatkan Kinerja Guru sebesar 0.481 satuan demikian sebaliknya bila motivasi kerja menurun satu unit maka akan menurunkankan Kinerja Guru sebesar 0.481 satuan. variabel independen yang ketiga yaitu disiplin kerja memiliki nilai koefisien regresi sebesar 0.702 artinya bila disiplin guru meningkat satu unit maka akan meningkatkan Kinerja Guru 0.702 satuan, demikian sebaliknya bila kompetensi guru menurun satu unit maka akan menurunkan Kinerja Guru 0.702 satuan.

Tabel 4 Uji F Variabel Kepemimpinan, Motivasi dan Kompetensi Guru serta Pengaruhnya terhadap Kinerja Guru 
Jurnal EKOBISTEK , Vol.8, No. 2, Okto6er 2019, Hal 32-36, ISSN : 2301-5268 | E-ISSN : 2527-9483

Copyright@2018 6y LPPM VPI YPTK Padang

\begin{tabular}{|c|c|c|c|c|c|c|}
\hline Model & & $\begin{array}{c}\text { Sum of } \\
\text { Squares }\end{array}$ & $\overline{d f}$ & Mean Square & $\mathrm{F}$ & Sig. \\
\hline & Regression & 328.204 & 3 & 9.401 & 11.141 & $0.04^{b}$ \\
\hline 1 & Residual & 321.424 & 39 & 8.242 & & \\
\hline & Total & 649.628 & 42 & & & \\
\hline
\end{tabular}

Dari tabel di atas, diperoleh $\mathrm{F}_{\text {hitung }}=11.141$ sedangkan $\mathrm{F}_{\text {tabel }}$ pada $\alpha=0,05$ sebesar 2.845; jadi $\mathrm{F}_{\text {hitung }}>$ $\mathrm{F}_{\text {tabel }}(11.141>2.845)$; maka Ho ditolak (salah satu $\beta \neq 0$ ). Dengan demikian terbukti bahwa secara bersama-sama terdapat pengaruh yang signifikan antara Gaya Kepemimpinan, Motivasi Kerja dan DisiplinKerja secara bersama-sama terhadap Kinerja Guru SMP Negeri 3 Salimpaung Kabuapten Tanah Datar. Oleh karena itu hipotesis yang menyatakan Gaya Kepemimpinan, Motivasi Kerja dan DisiplinKerja secara bersama-sama berpengaruh positif dan signifikan terhadap Kinerja Guru SMP Negeri 3 Salimpaung Kabupaten Tanah Datar" diterima.

\section{Kesimpulan}

Berdasarkan hasil penelitian yang dikemukakan pada bab sebelumnya maka dapat disimpulkan beberapa hal penting dalam penelitian ini yaitu:

1. Gaya Kepemimpinan diperolehnya nilai $t_{\text {hitung }}$ sebesar 2,089 $>t_{\text {tabel }}$ sebesar 2.022 , dengan nilai sig. 0.043 yang lebih kecil dari $\alpha$ 0,05. Sehingga secara parsial Gaya Kepemimpinan berpengaruh positif dan signifikan terhadap Kinerja Guru.

2. Motivasi Kerja diperolehnya nilai $t_{\text {hitung }}$ sebesar 2,546> $t_{\text {tabel }}$ sebesar 2,022, dengan nilai sig. 0,015 yang lebih kecil dari $\alpha$ 0,05. Sehingga secara parsial Motivasi Kerja berpengaruh positif dan signifikan terhadap Kinerja guru.

3. Disiplin Kerja diperolehnya nilai $t_{\text {hitung }}$ sebesar 2,388> $t_{\text {tabel }}$ sebesar 2,022, dengan nilai sig. 0,000 yang lebih kecil dari $\alpha$ 0,05. Sehingga secara parsial Disiplin Kerja berpengaruh positif dan signifikan terhadap Kinerja guru.

4. Dari tabel di atas, diperoleh $F_{\text {hitung }}=11.141$ sedangkan $F_{\text {tabel }}$ pada $\alpha=0,05$ sebesar 2.845; jadi $\mathrm{F}_{\text {hitung }}>\mathrm{F}_{\text {tabel }}(11.141>2.845)$ dengan nilai sig.0,04 yang lebih kecil dari $\alpha 0.05$, sehingga secara bersama Gaya Kepemimpinan, Motivasi Kerja dan DisiplinKerja berpengaruh positif dan signifikan terhadap Kinerja Guru SMP Negeri 3 Salimpaung Kabuapten Tanah Datar. 


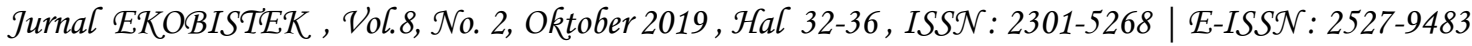

Copyright@2018 by LPPM VPI YPT'K Padang

\section{DAFTAR PUSTAKA}

[1] Amral. 2016. "Analisis pengaruh sertifikasi guru,motivasi kerja dan disiplin kerja terhadap kinerja guru SMA Negeri 2 Koto Baru Kabupaten Dharmasraya". Tesis UPI "YPTK” Padang.

[2] Ariza, Zul . 2016." Pengaruh kepemimpinan kepala sekolah,motivasi kerja dan disiplin kerja terhadap kinerja guru SMPN 2 Sijunjung Kabupaten Sijunjung”. Tesis . UPI "YPTK" Padang.

[3] Bangun. 2012. Manajemen Sumber Daya Manusia. Jakarta: Erlangga.

[4] Berliana, 2010. Motivasi Meditasi . Jakarta : growing publishing.

[5] Danim. 2012.Motivasi Kepemimpinan dan Efektivitas Kelompok. Jakarta : Rineka Cipta.

[6] Edisa,Herri . 2017 . "Pengaruh kompetensi guru,motivasi kerja dan iklim organisasi terhadap Kinerja guru SMAN 6 Kabupaten Kerinci" Tesis. UPI "YPTK" Padang.

[7] Fernandes, Adek. 2015. Pengaruh gaya kepemimpinan, budaya organisasi dan lingkungan kerja terhadap kinerja guru SMK Negeri 1 Rambah Kabupaten Rokan Hulu.Tesis UPI "YPTK" Padang.

[8] Hasibuan. 2014. Manajemen Sumber Daya Manusia. Jakarta: PT Bumi Aksara.

[9] Herzberg . 2006. Psikologi Pengajaran . Yogyakarta : Media Abadi.

[10] J. Supranto dan Nandan Limakrisna. 2012. Petunjuk Praktis Penelitian Ilmiah untuk Menyusun Skripsi,Tesis dan Disertasi . Jakarta : Mitra Wacana Media.

[11] Masngudi. 2012. Metodologi Penelitian Untuk Ekonomi \& Bisnis. Jakarta ： Trianandra University Press.

[12] Mathis dan Jackson, 2011. Manajemen Sumber Daya manusia, Jakarta :Salemba Empat .

[13] Moeheriono . 2012. Pengukuran Kinerja berbasis kompetensi ( Edisi Revisi). Jakarta : Rajawali Pers.

[14] Pramana, Handra. 2016. " Pengaruh gaya kepemimpinan, motivasi dan disiplin kerja terhadap kinerja pegawai dinas sosial tenaga kerja dan transmigrasi Kabupaten Pasaman Barat”. Tesis . UPI "YPTK" Padang.

[15] Priyatno. 2011. Mandiri Belajar SPSS. Yogyakarta, Mediakom.

[16] Rivai. 2014. Manajemen Sumber Daya Manusia Untuk Perusahaan Dari Teori Ke Praktek. Jakarta: PT. Raja Grafindo Persada.

[17] Robbins. 2014. Organizational Behavior, New Jersey, Prentice Hall.

[18] Sekaran, U. 2013. Metode Penelitian Untuk Bisnis. Jakarta: Erlangga.

[19] Sutrisno. 2012. Manajemen Sumber Daya Manusia. Jakarta: Kencana.

[20] Sukmasari, Hentry. 2011. "Pengaruh kepemimpinan, motivasi, insentif, lingkungan kerja, dan kepuasan kerja terhadap kinerja pegawai dinas pengelolaan keuangan dan aset kota semarang”. Tesis . Universitas Dian Nuswantoro.

[21] Sugiyono. 2012. Metode penelitian Bisnis. Bandung : Alfabeta.

[22] Suliyanto. 2011, Ekonomiterika Terapan, Teori \& Aplikasi. Yogyakarta, Andi Offset.

[23] Supardi. 2014. Kinerja Guru. Jakarta: Raja Grafindo Persada.

[24] Sutikno ,2014. Pemimpin dan Kepemimpinan: Tips Praktis untuk Menjadi Pemimpin diidolakan. Lombok: Holistica Lombok

[25] Sutrisno. 2012. Manajemen Sumber Daya Manusia. Edisi 1. Cetakan Keempat. Jakarta, Prenada Media Group.

[26] Thoha.2015. Perilaku Organisasi , Konsep Dasar dan Aplikasinya . Jakarta : Raja Grafindo Perkasa.

[27] Uno. 2013. Teori Motivasi dan Pengukurannya . Jakarta : Bumi Aksara.

[28] Uno,2014. Psikologi Sosial . Bandung Refika Aditama

[29] Wardana, Kusuma Yoga. 2014. "Pengaruh gaya kepemimpinan ,motivasi dan disiplin kerja terhadap kinerja (studi kasus pada Kantor Kecamatan Cisauk kabupaten Tanggerang”. Tesis . Universitas Islam Negri Syarif Hidayatullah.

[30] Yamin dan Maisah . 2010. Kepemimpinan dan Manajemen Masa Depan. Bogor : IPB Press. 